\title{
Poly( $\beta$-L-aspartate)s Containing Ethylene Oxide Units in the Side Chain: Synthesis and Structural Studies
}

\author{
F. LóPez-CARrasquero, A. Martínez de Ilarduya, \\ and S. MuÑoz-GuERRA* \\ Departamento de Ingeniería Química, Universidad Politécnica de Cataluña \\ E.T.S. de Ingenieros Industriales, Diagonal 64708028 Barcelona, Spain
}

(Received October 12, 1993)

\begin{abstract}
Two poly $\left(\beta\right.$-L-aspartate)s of general formula $\left[\mathrm{HN}-\mathrm{CH}(\mathrm{COOR})-\mathrm{CH}_{2}-\mathrm{CO}\right]$ containing ethylene oxide units in the side chain $\left[\mathrm{R}=-\mathrm{CH}_{2} \mathrm{CH}_{2} \mathrm{OCH}_{3}\right.$ (IVa), and $-\mathrm{CH}_{2}$ $\mathrm{CH}_{2} \mathrm{OCH}_{2} \mathrm{CH}_{2} \mathrm{OCH}_{3}$ (IVb)] have been prepared by anionic ring-opening polymerization of the corresponding optically pure $\beta$-lactams. In both cases, stereoregular polymers with molecular weights above $2 \times 10^{5}$ were obtained in satisfactory yields. These polyamides were fully characterized by combustion analysis, FTIR and ${ }^{1} \mathrm{H}-{ }^{13} \mathrm{C}$ NMR spectroscopy, and DSC. Whereas polymer IVa attained was completely free of imide units, side reactions giving rise to imidation could not be entirely repressed in the polymerization of the $\beta$-lactam leading to IVb. X-Rays from oriented samples revealed that polymer IVa crystalizes in a hexagonal structure made up of $4^{*} 13 / 4$ helices which bear great conformational resemblance with the well known $\alpha$-helix in polypeptides. A similar conformation seems to be adopted by polymer IVb, although in this case, side chains tend to remain in a disordered state hindering the crystallization of the helices.
\end{abstract}

KEY WORDS Nylons / Polyamides / Poly $(\beta$-L-aspartates) / Stereoregular Polyamides / Nylon-3 /

It is well known that both $\operatorname{poly}(\alpha-\mathrm{L}-$ aspartate)s and poly( $\alpha$-L-glutamate)s take up stable $\alpha$-helical conformations for a wide variety of lateral substituents. ${ }^{1}$ In order to examine the effects of the side chain on crystal structure and conformation as well as on related properties, extensive research on these two families of polypeptides has been realized within the last four decades. ${ }^{2}$ On the contrary, $\operatorname{poly}(\beta$-L-aspartate $) s$ and poly $(\gamma$-L-glutamate $)$, which may be envisaged derivatives of nylon-3 and -4 , respectively, have been barely studied so far. Nevertheless, it was a few years ago when we found that the isobutyl ester of poly( $\beta$-L-aspartic acid) is able to adopt molecular conformations of $\alpha$-helix type upon crystallization and to retain this structure even in solution. ${ }^{3,4}$ New properties without parallel in the family of nylons, as liquid crystal formation $^{5}$ and piezoelectricity, ${ }^{6}$ were observed for this poly- $\beta$-aminoacid derivative. Recently it has been further shown that such behavior is common to the whole family of alkyl esters of $\operatorname{poly}(\beta$-L-aspartate)s, irrespective of the constitution of the side chain. ${ }^{7}$

However no $\operatorname{poly}(\beta$-L-aspartate) with attached side chains other than alkyl has been studied so far. In this paper we wish to report on two new poly $(\beta$-L-aspartate)s which contain ethylene oxide units in the side chain, namely poly $[\alpha-(2$-methoxy-ethyl)- $\beta$-L-aspartate $]$ (IVa) and poly $[\alpha-(2-m e t h o x y e t h o x y-e t h y l)-\beta$-Laspartate) (IVb), abbreviated PAMELA and PAMEELA, respectively. A marked enhancement in both side chain motion and polarity may be anticipated for these polymers when

\footnotetext{
* To whom correspondence should be addressed.
} 
compared with their analogous alkyl esters. In fact, it has been published that poly $[\gamma-$ methoxy-oligo(ethylene oxide)-L-glutamate]s exhibit ionic transport properties associated with the low relaxation temperature of the side chain while the main chain is arranged in the rigid $\alpha$-helical conformation. ${ }^{8}$ With the aim of investigating how the presence of ethylene oxide groups in side chains of different lengths may influence the conformational behavior of poly( $\beta$-L-aspartates), a comprehensive study including synthesis and characterization as well as the X-ray analysis of the structure in the solid state, has been carried out on the two compounds named above.

\section{EXPERIMENTAL}

\section{Materials and Methods}

All reagents and solvents were analytical grade or higher. L-Aspartic acid $\left([\alpha]_{\mathrm{D}}^{25}\right.$ $+24.7 \pm 0.5$, c 5 , in $\mathrm{HCl}$ ) was supplied by Fluka. All solvents were exhaustively dried according to standard procedures. ${ }^{9}$

Melting points of organic compounds were measured in a Gallenkamp apparatus and are uncorrected. Elemental microanalyses were performed by the Servei de Microanàlisi (CSIC, Barcelona). For estimation of molecular weights, intrinsic viscosities were measured at $25^{\circ} \mathrm{C}$ in dichloroacetic acid in a Ubbelohde microviscometer. Infrared spectra were registered in a Perkin-Elmer 2000 instrument from samples in $\mathrm{KBr}$ disks or films prepared by casting. NMR spectra were recorded on a Bruker AMX-300 spectrometer operating at 300.13 and $70.48 \mathrm{MHz}$ for ${ }^{1} \mathrm{H}$ and ${ }^{13} \mathrm{C}$, respectively. Tetramethylsilane was used as internal reference standard and the internal lock was $\mathrm{CDCl}_{3} \cdot{ }^{1} \mathrm{H}-{ }^{1} \mathrm{H}$ Homonuclear and ${ }^{1} \mathrm{H}-{ }^{13} \mathrm{C}$ heteronuclear (short and long range couplings) shift correlation $2 \mathrm{D}$ spectra were recorded by means of the pulse sequences COSY, HXCO, and COLOC, respectively. Thermal analyses were carried out on a Perkin-Elmer DSC-4 instrument at heating rates of $10^{\circ} \mathrm{Cmin}^{-1}$, under nitrogen atmosphere. Densities were measured by flotation in carbon tetrachloride-toluene mixtures at $25^{\circ} \mathrm{C}$. For X-ray diffraction the samples were placed in a vacuum to remove air scatter, and the diffraction pattern was recorded on flat film using pinhole collimation and nickel-filtered $\mathrm{Cu}-K_{\alpha}$ radiation of wavelength $0.1542 \mathrm{~nm}$. Internal calibration was made with molybdenum sulphide $\left(d_{002}: 0.6147 \mathrm{~nm}\right)$.

\section{Synthesis of Monomers}

(S)-4-Benzyloxycarbonyl-2-azetidinone (II) was prepared according to Salzmann ${ }^{10}$ from L-aspartic acid (I) via the Grignard mediated cyclization of the $\mathrm{N}$-trimethylsilyl L-aspartate dibenzyl ester. $\mathrm{mp} 139-140^{\circ} \mathrm{C},[\alpha]_{\mathrm{D}}^{25}-38.7^{\circ}$ (c 1.01, in $\mathrm{CHCl}_{3}$ ). Lit. ${ }^{11} 139-140^{\circ} \mathrm{C},[\alpha]_{\mathrm{D}}^{25}$ $-35.7^{\circ}$ (c 1.12, in $\left.\mathrm{MeOH}\right)$.

(S)-4-(2-Methoxy-ethoxycarbonyl)-2-azetidinone (IIIa). $2.05 \mathrm{~g}$ of 4-(S)-benzyloxy-carbonyl-2-azetidinone (II) and $0.1 \mathrm{~g}$ of titanium (IV) tetrabutoxide were dissolved in 2-methoxyethanol $(19 \mathrm{ml})$ and the solution refluxed at $121^{\circ} \mathrm{C}$ for 6 hours. After cooling, the glycol in excess as well as the formed benzyl alcohol were removed by distillation under vacuum. The residue was then diluted with water $(5 \mathrm{ml})$, extracted with chloroform $(5 \mathrm{ml})$ and the chloroform solution repeatedly extracted with water $(5 \times 5 \mathrm{ml})$. The aqueous extracts were pooled and concentrated to dryness by rotavaporation maintaining the temperature below $40^{\circ} \mathrm{C}$. Crystallization of the oily residue in ethyl acetate-hexane afforded compound IIIa as yellowish needles which were further purified to a white solid by distillation under vacuum $\left(150^{\circ} \mathrm{C} / 0.02\right.$ Toor $)$. Yield $0.70 \mathrm{~g}(42 \%)$, mp 62- $63^{\circ} \mathrm{C},[\alpha]_{\mathrm{D}}^{25}-37.0^{\circ}\left(c 0.99\right.$, in $\left.\mathrm{CHCl}_{3}\right)$. Anal. Calcd for $\mathrm{C}_{7} \mathrm{H}_{11} \mathrm{O}_{4} \mathrm{~N}$ (173.07): C, $48.54 \%$; H, 6.41\%; N, 8.09\%. Found: C, $48.50 \% ; \mathrm{H}, 6.47 \% ; \mathrm{N}, 8.06 \%$. IR $\left(\mathrm{cm}^{-1}\right.$, in $\left.\mathrm{CH}_{2} \mathrm{Cl}_{2}\right): 3274(\mathrm{NH}$, amide $\mathrm{A}), 1780(\mathrm{C}=\mathrm{O}$, ester), 1747 ( $\mathrm{C}=\mathrm{O}$, amide I), 1455 (amide II). ${ }^{1} \mathrm{H} \mathrm{NMR}$ (in $\mathrm{CDCl}_{3}$ ): $\delta, 6.79$ (s, $1 \mathrm{H}, \mathrm{NH}$ ), 4.34 $\left(\mathrm{m}, 2 \mathrm{H}, \mathrm{COOCH}_{2}\right), 4.23(2 \mathrm{~d}, 1 \mathrm{H}, \mathrm{CONHCH})$, 
$3.62\left(\mathrm{~m}, 2 \mathrm{H}, \mathrm{COOCH}_{2} \mathrm{CH}_{2}\right), 3.39\left(\mathrm{~s}, 3 \mathrm{H}, \mathrm{CH}_{3}\right)$, $3.35\left(\mathrm{~m}, 1 \mathrm{H}, \mathrm{CH}_{2} \mathrm{CONH}\right), 3.10(\mathrm{~m}, 1 \mathrm{H}$, $\mathrm{CH}_{2} \mathrm{CONH}$ ). ${ }^{13} \mathrm{C}$ NMR (in $\mathrm{CDCl}_{3}$ ): $\delta, 171.09$ (COO), 166.33 (CONH), $70.13\left(\mathrm{CH}_{2} \mathrm{OCH}_{3}\right)$, $64.59\left(\mathrm{COOCH}_{2}\right), 59.00\left(\mathrm{CH}_{3}\right), 47.22(\mathrm{CONH}-$ $\mathrm{CH}), 43.67\left(\mathrm{CH}_{2} \mathrm{CONH}\right)$.

(S)-4-[2-(2-Methoxy-ethoxy)-ethoxycarbonyl]-2-azetidinone (IIIb). Transesterification of compound II $(1.05 \mathrm{~g})$ with 2-(2-methoxyethoxy)-ethanol $(5 \mathrm{ml})$ in the presence of $0.05 \mathrm{~g}$ of titanium (IV) tetrabutoxide was carried out at $125^{\circ} \mathrm{C}$ for 5 hours. Isolation and purification of the title compound IIIb was accomplished in substantially the same manner as described above for IIIa. Yield $0.60 \mathrm{~g}(59 \%)$, mp 46 $47^{\circ} \mathrm{C},[\alpha]_{\mathrm{D}}^{25}-19.6^{\circ}$ (c 1.0, in $\mathrm{CHCl}_{3}$ ). Anal. Calcd for $\mathrm{C}_{9} \mathrm{H}_{15} \mathrm{O}_{5} \mathrm{~N}$ (217.09): $\mathrm{C}, 49.75 \% ; \mathrm{H}$, $6.96 \% ; \mathrm{N}, 6.45 \%$. Found: C, $49.88 \% ; \mathrm{H}$, $7.06 \%$;, $6.46 \%$. IR $\left(\mathrm{cm}^{-1}\right.$, in $\left.\mathrm{CH}_{2} \mathrm{Cl}_{2}\right): 3287$ ( $\mathrm{NH}$, amide $\mathrm{A}), 1781(\mathrm{C}=\mathrm{O}$, ester), 1746 (C=O, amide I), 1456 (amide II). ${ }^{1} \mathrm{H}$ NMR (in $\left.\mathrm{CDCl}_{3}\right): \delta, 6.29(\mathrm{~s}, 1 \mathrm{H}, \mathrm{NH}), 4.36(\mathrm{~m}, 2 \mathrm{H}$, $\left.\mathrm{COOCH}_{2}\right), 4.21(2 \mathrm{~d}, 1 \mathrm{H}, \mathrm{CONHCH}), 3.73(\mathrm{~m}$, $\left.2 \mathrm{H}, \mathrm{COOCH}_{2} \mathrm{CH}_{2}\right), 3.64\left(\mathrm{~m}, 2 \mathrm{H}, \mathrm{CH}_{2} \mathrm{CH}_{2}-\right.$ $\left.\mathrm{OCH}_{3}\right), 3.56\left(\mathrm{~m}, 2 \mathrm{H}, \mathrm{CH}_{2} \mathrm{OCH}_{3}\right), 3.38(\mathrm{~s}, 3 \mathrm{H}$, $\left.\mathrm{CH}_{3}\right), 3.33\left(\mathrm{~m}, 1 \mathrm{H}, \mathrm{CH}_{2} \mathrm{CONH}\right), 3.11(\mathrm{~m}, 1 \mathrm{H}$, $\mathrm{CH}_{2} \mathrm{CONH}$ ). ${ }^{13} \mathrm{C}$ NMR (in $\mathrm{CDCl}_{3}$ ): $\delta, 171.06$ (COO), 166.47 (CONH), $71.76\left(\mathbf{C H}_{2} \mathrm{OCH}_{3}\right)$, $70.41\left(\mathrm{CH}_{2} \mathrm{CH}_{2} \mathrm{OCH}_{3}\right), 68.70\left(\mathrm{COOCH}_{2} \mathrm{CH}_{2}\right)$, $64.49\left(\mathrm{COOCH}_{2}\right), 58.97\left(\mathrm{CH}_{3}\right), 47.16(\mathrm{CONH}-$ $\mathrm{CH}), 43.44\left(\mathrm{CH}_{2} \mathrm{CONH}\right)$.

\section{Synthesis of Polymers}

General Procedure. To a solution of $x \mathrm{~mol}$ of III in dichloromethane at a concentration of $18 \%(\mathrm{w} / \mathrm{w}), x / 25 \mathrm{~mol}$ of sodium pyrrolidone were added under vigorous stirring at room temperature. The reaction was left to proceed for 24 hours after which, the formed polymer was precipitated by adding methanol or ethanol (IVa or IVb) and repeatedly washed with ethyl ether. Further purification was carried out by dissolving the polymer in DMSO and precipitating it with methanol or a mixture of ethanol-ethyl ether ( $1: 3$ ) (IVa or IVb). The product was recovered as a white powder which was finally dried under vacuum.

Poly[ $\alpha$-(2-methoxy-ethyl)- $\beta$-L-aspartate $]$ (IVa) (PAMELA) was prepared from IIIa in $76 \%$ yield. [ $\eta$ ]: $3.35 \mathrm{~g} \mathrm{dl}^{-1}$. Anal. Calcd for $\left(\mathrm{C}_{7} \mathrm{H}_{11} \mathrm{O}_{4} \mathrm{~N}\right)_{n}: \mathrm{C}, 48.54 \% ; \mathrm{H}, 6.41 \% ; \mathrm{N}$, $8.09 \%$. Found: C, $48.47 \% ; \mathrm{H}, 6.46 \% ; \mathrm{N}$, $8.09 \%$. IR $\left(\mathrm{cm}^{-1}\right.$, film cast from 2-chloroethanol): 3287 (NH, amide A), 3086 (amide B), $1747(\mathrm{C}=\mathrm{O}$, ester $), 1655(\mathrm{C}=\mathrm{O}$, amide $\mathrm{I}), 1546$ (amide II), 1178 (C-O, ester), 1125 (C-O, ether) 667 (amide V). ${ }^{1} \mathrm{H}$ NMR (in $\mathrm{CDCl}_{3}$-TFA $(5: 2)): \delta, 8.05(\mathrm{~d}, 1 \mathrm{H}, \mathrm{NH}), 5.03(\mathrm{~m}, 1 \mathrm{H}$, CONHCH $), 4.50\left(\mathrm{~m}, 2 \mathrm{H}, \mathrm{COOCH}_{2}\right), 3.92(\mathrm{~m}$, $\left.2 \mathrm{H}, \mathrm{COOCH}_{2} \mathrm{CH}_{2}\right), 3.60\left(\mathrm{~s}, 3 \mathrm{H}, \mathrm{OCH}_{3}\right), 3.20$ (m, $2 \mathrm{H}, \mathrm{CH}_{2} \mathrm{CONH}$ ). ${ }^{13} \mathrm{C} \mathrm{NMR}$ (in $\mathrm{CDCl}_{3}-$ TFA $(5: 2)): \delta, 174.14$ (CONH), $173.46(\mathrm{COO})$, $71.48\left(\mathrm{CH}_{2} \mathrm{OCH}_{3}\right), 66.38\left(\mathrm{COOCH}_{2}\right), 59.56$ $\left(\mathrm{CH}_{3}\right), 51.24(\mathrm{CONHCH}), 37.94\left(\mathrm{CH}_{2} \mathrm{CONH}\right)$.

Poly[ $\alpha-(2$-methoxyethoxy-ethyl)- $\beta$-L-aspartate] (IVb) (PAMEELA) was prepared from IIIb in $67 \%$ yield. [ $\eta]$ : $2.52 \mathrm{~g} \mathrm{dl}^{-1}$. Anal. Calcd for $\left(\mathrm{C}_{9} \mathrm{H}_{15} \mathrm{O}_{5} \mathrm{~N}\right)_{n}: \mathrm{C}, 49.75 \% ; \mathrm{H}, 6.96 \%$; N, 6.45\%. Found: C, 48.10\%; H, 6.37\%; N, $7.58 \%$. IR $\left(\mathrm{cm}^{-1}\right.$, film cast from 2-chloroethanol): 3286 (amide A), 3086 (amide B), $1733(\mathrm{C}=\mathrm{O}$, ester $), 1655(\mathrm{C}=\mathrm{O}$, amide $\mathrm{I}), 1545$ (amide II), 1177 (C-O, ester), 1112 (C-O, ether), 658 (amide V). ${ }^{1} \mathrm{H}$ NMR (in $\mathrm{CDCl}_{3}$ TFA (1:9): $\delta, 8.13(\mathrm{~d}, 1 \mathrm{H}, \mathrm{NH}), 5.10(\mathrm{~m}, 1 \mathrm{H}$, $\mathrm{CONHCH}), 4.55\left(\mathrm{~m}, 2 \mathrm{H}, \mathrm{COOCH}_{2}\right), 4.01(\mathrm{~m}$, $\left.4 \mathrm{H}, \mathrm{CH}_{2} \mathrm{OCH}_{2}\right), 3.94\left(\mathrm{~m}, 2 \mathrm{H}, \mathrm{COOCH}_{2} \mathrm{CH}_{2}\right)$, 3.64 (s, $\left.3 \mathrm{H}, \mathrm{CH}_{3}\right), 3.25\left(\mathrm{~m}, 2 \mathrm{H}, \mathrm{CH}_{2} \mathrm{CONH}\right)$. ${ }^{13} \mathrm{C}$ NMR (in $\mathrm{CDCl}_{3}$-TFA $(1: 9)$ ): $\delta, 174.34$ $(\mathrm{CONH}), 173.55(\mathrm{COO}), 72.50\left(\mathrm{CH}_{2} \mathrm{OCH}_{3}\right)$, $70.99\left(\mathrm{CH}_{2} \mathrm{CH}_{2} \mathrm{OCH}_{3}\right), 70.26\left(\mathrm{COOCH}_{2} \mathbf{C H}_{2}\right)$, $66.58\left(\mathrm{COOCH}_{2}\right), 59.40\left(\mathrm{CH}_{3}\right), 51.43(\mathrm{CONH}-$ $\mathrm{CH}), 38.06\left(\mathrm{CH}_{2} \mathrm{CONH}\right)$.

\section{RESULTS AND DISCUSSION}

\section{Synthesis}

A synthetic route similar to that previously reported for the synthesis of poly $(\alpha$-alkyl- $\beta$-Laspartate)s ${ }^{7}$ has been followed here for the preparation of poly $(\beta$-L-aspartate)s containing ethylene oxide units in the side chain. The 
reaction scheme of the synthesis is outlined in Figure 1. For the preparation of $\beta$-lactam monomers, $(S)$-4-benzyloxycarbonyl-2-azetidinone (II) was subjected to transesterification with 2-methoxy-ethanol or 2-(2-methoxyethoxy)ethanol, in the presence of catalytic amounts of titanium(IV)-tetrabutoxide. By this procedure, optically active compounds IIIa and IIIb could be prepared in good yields.

Both poly( $\beta$-L-aspartate)s IVa and IVb were obtained by anionic ring-opening polymerization of the corresponding $\beta$-lactams IIIa and IIIb in dichloromethane solution at room temperature. Sodium pyrrolidone was used as catalyst but no $\mathrm{N}$-acyllactam initiator of the type commonly used in this kind of polymerizations, was added. Under these conditions, high

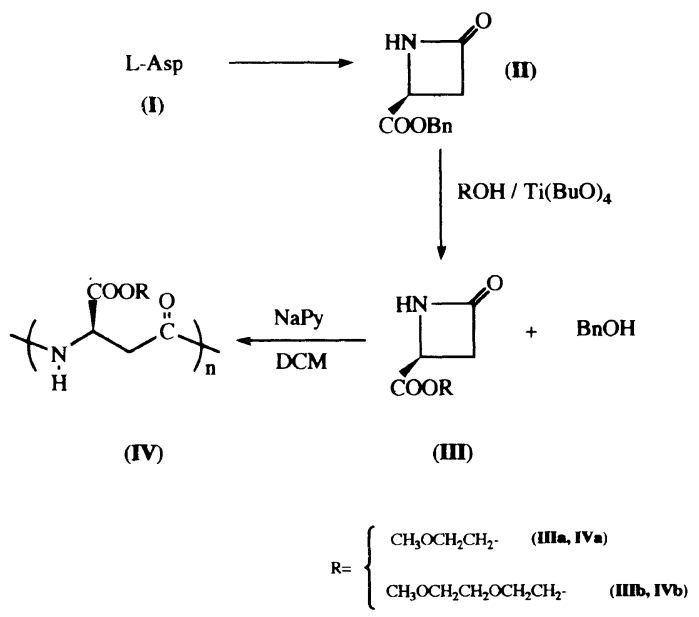

Figure 1. Scheme of the synthetic route followed for the preparation of poly( $\alpha$-alkoxy- $\beta$-L-aspartate)s (IV). molecular weight polymers were obtained in satisfactory yields (Table I).

It is known that side imidation reactions usually take place in the polymerization of $\beta$-lactams with a carboxylate group substituted at the 4 position. ${ }^{11}$ The extent to which such side reactions occur has been shown to increase with both the polarity of the solvent and the electron withdrawing character of the attached side chain. ${ }^{14}$ Given the good leaving character which may be anticipated for alkoxy groups containing ethylene oxide units, a low polar solvent (DCM) was selected for the polymerization of lactams IIIa and IIIb in compensation. Since the catalyst is not soluble in this type of solvents, the reaction proceeded under heterogeneous conditions. This represents a drawback when compared with polymerizations in dimethyl sulphoxide, a highly polar solvent widely used in the preparation of poly- $\beta$-amides from $\beta$-lactams exhibiting less propensity to undergo imidation reactions. ${ }^{15}$

\section{Polymer Characterization}

Elemental analyses assessed the chemical constitution anticipated for these polymers. Whereas for PAMELA, calculated and measured values were in full concordance, differences in values slightly above the formally acceptable limits were found in the analysis of PAMEELA. Summing up the contributions of minor impurities from a variety of sources should be assumed to account for such deviations. One is imidation occurring in the polymer as it will be discussed below. A second

Table I. Polymerization data and properties of poly $(\beta$-L-aspartate $) \mathrm{s}$

\begin{tabular}{lcccccc}
\hline Polymer & Yield $/ \%$ & {$[\eta] / \mathrm{dl} \mathrm{g}^{-1 \mathrm{a}}$} & $M_{v} \times 10^{-5 \mathrm{~b}}$ & \multicolumn{1}{c}{$\rho / \mathrm{g} \mathrm{ml}^{-1 \mathrm{c}}$} & $T_{\mathrm{d}}{ }^{\circ} \mathrm{C}^{\mathrm{d}}$ \\
\hline PAMELA (IVa) & 76 & 3.35 & 6.9 & 3.1 & 1.339 & 222 \\
PAMEELA (IVb) & 67 & 2.52 & 5.0 & 2.6 & 1.296 & 209 \\
\hline
\end{tabular}

${ }^{\text {a }}$ Measured in DCA at $25^{\circ} \mathrm{C}$.

${ }^{b}$ Estimated by using the parameters of the viscosimetric equations reported for poly $(\gamma \text {-benzyl-L-glutamate })^{12}$ and poly $\left(\gamma\right.$-methyl-L-glutamate).$^{13}$

c Measured by flotation in carbon tetrachloride/toluene mixtures.

d Temperatures corresponding to maxima of endotherms registered by DSC. 


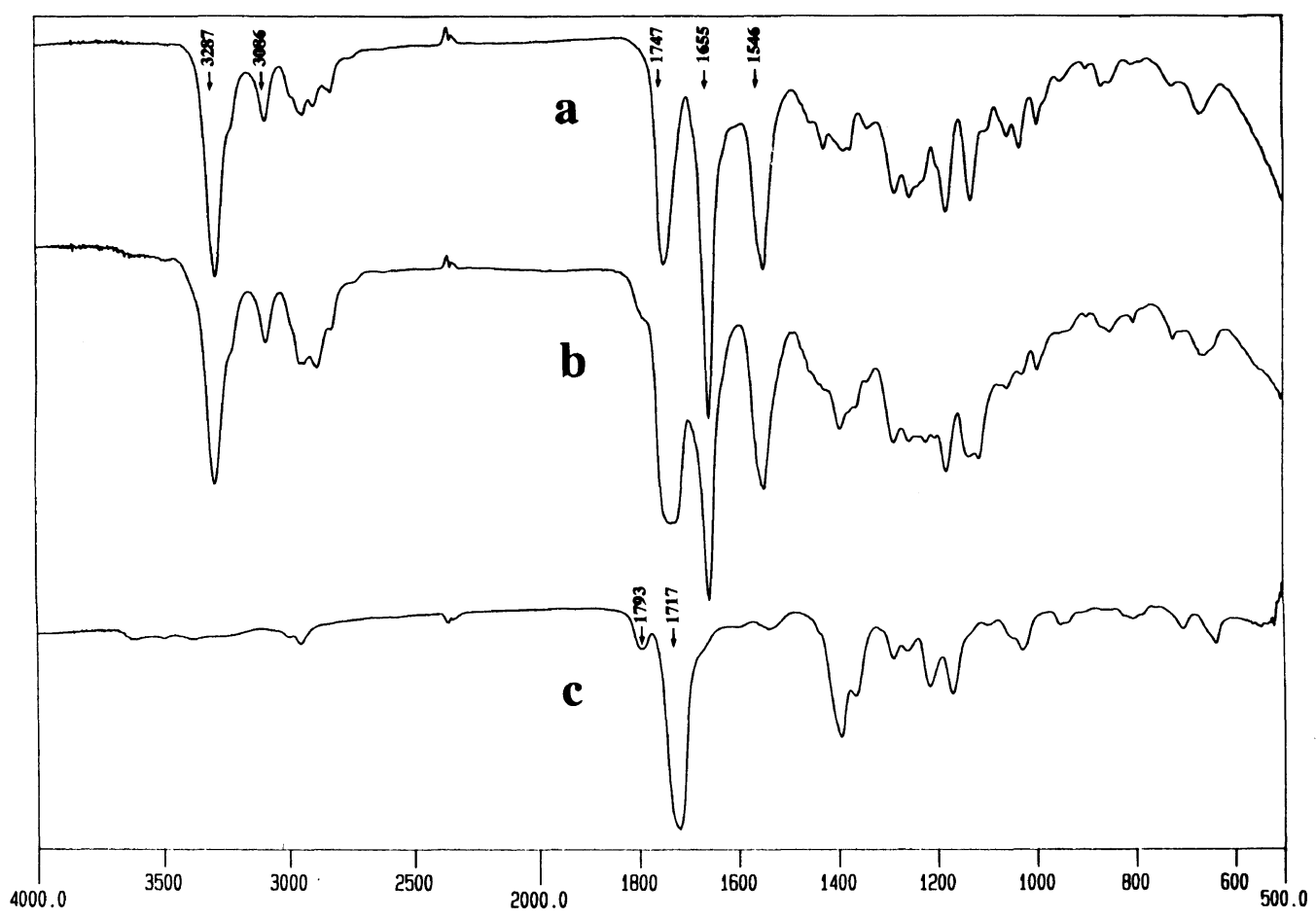

CM-1

Figure 2. Infrared spectra of polymers. (a) PAMELA; (b), PAMEELA; (c), PAMELA recovered from a solution of DMSO containing traces of sodium pyrrolidone. Absortions at 1793 and $1717 \mathrm{~cm}^{-1}$ are characteristic of aspartimide units. ${ }^{11}$

one arises from incomplete removal of sodium pyrrolidone from the prepared polymer as evidenced by ${ }^{1} \mathrm{H}$ NMR spectroscopy. Finally, a certain amount of water firmly bound to the hydrophilic side chain may be presumed to be present too.

The infrared spectra showed the characteristic absorption of polyamides together with those arising from $\mathrm{C}-\mathrm{O}-\mathrm{C}$ bonds contained in the side chain. However the spectrum of PAMEELA exhibited a considerable broadening of the amide I band together with a small absorption at $1780 \mathrm{~cm}^{-1}$ as a shoulder of the ester $\mathrm{C}=\mathrm{O}$ peak (Figure 2). These features evidenced the presence of imide units in this polymer in a content which may be estimated lower than $5 \%$.

Both ${ }^{1} \mathrm{H}$ and ${ }^{13} \mathrm{C}$ NMR spectra showed peaks at chemical shifts and multiplicities in agreement with the $-\mathrm{HN}-{ }^{*} \mathrm{CH}-\mathrm{CH}_{2} \mathrm{CO}-$ structure of the backbone repeating unit of these polymers. In particular, two multiplets at around 5.0 and $3.2 \mathrm{ppm}$, corresponding to an ABX system composed of the diastereotopic pair of protons on the $\beta$-carbon and the proton on the $\alpha$-carbon are observed in the ${ }^{1} \mathrm{H}$ NMR spectra; these signals are characteristic of poly $(\beta$-L-aspartate $)$ s. $^{3}$ On the other hand, signals at $174.1-174.4,51.2-51.5$, and 37.9-38.1 appear in the ${ }^{13} \mathrm{C}$ spectra, which identify the three backbone carbon atoms of the $\beta$-amide unit.

Nevertheless, the ${ }^{1} \mathrm{H}$ spectrum of PAMEELA displays additional signals at 2.41, 2.87, and $3.81 \mathrm{ppm}$ characteristic of pyrrolidone, whose intensities indicate that a significant fraction of the catalyst used for polymerization has been retained in the sample (Figure 3). 


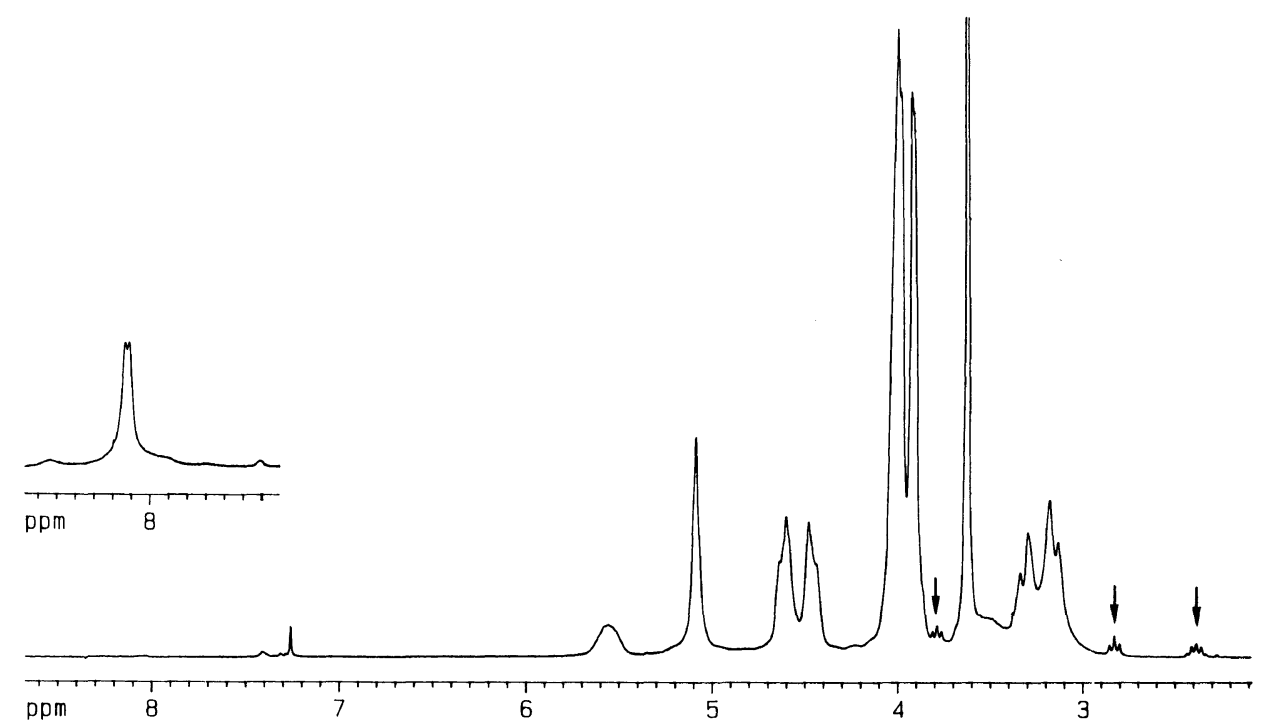

Figure 3. ${ }^{1} \mathrm{H}$ NMR spectrum of PAMEELA in $\mathrm{CDCl}_{3}-\mathrm{TFA}-d_{1}(1: 9)$. Signals arising from pyrrolidone are arrowed. Inset: signal corresponding to the NH that appears when the spectrum is recorded in non-deuterated TFA.

Moreover, two broad signals are also observed at 5.55 and $3.50 \mathrm{ppm}$ which are related to the $-\mathrm{CH}-\mathrm{CH}_{2}-$ group at the imide units.

To help in the assignment of signals associated to the side chains, ${ }^{1} \mathrm{H}-{ }^{1} \mathrm{H}$ homonuclear shift correlation spectra (COSY) were first registered from the corresponding 4(alkyloxycarbonyl)-azetidinones IIIa and IIIb. By this means, protons on side chain methylenes could be unambigously identified, as denoted in EXPERIMENTAL. COSY spectra from polymers IVa and IVb displayed similar correlations although in the case of PAMEELA signals partially overlaid. Afterwards ${ }^{1} \mathrm{H}-{ }^{13} \mathrm{C}$ heteronuclear shift correlation 2D spectra via both short and long range coupling were recorded. Figure 4 shows the HXCO spectrum of PAMELA which revealed that the more shielded methylene protons of the $-\mathrm{OCH}_{2}-$ $\mathrm{CH}_{2} \mathrm{O}$ - group correlate with the less shielded carbons and vice versa. A similar reversed correlation was also found for the two ethylene oxide groups contained in the side chain of PAMEELA. On the other hand, the assignment of signals arising from ester and amide

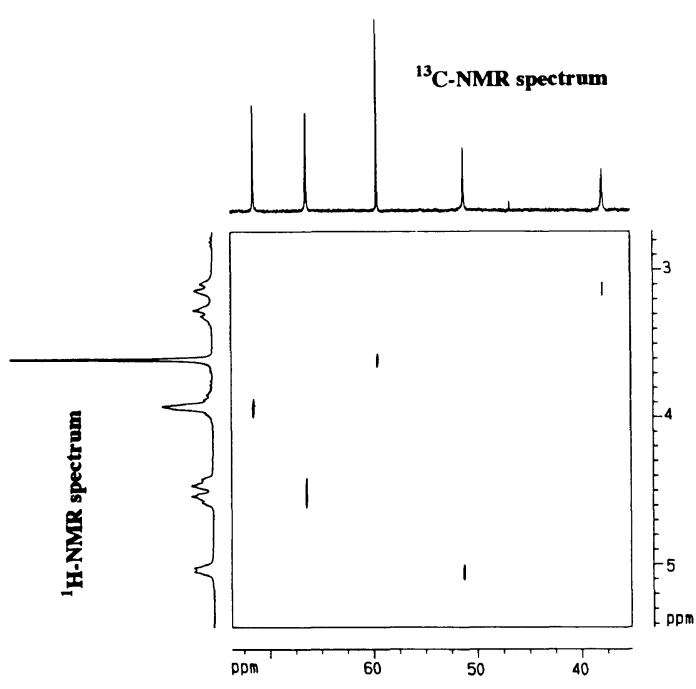

Figure 4. ${ }^{1} \mathrm{H}-{ }^{13} \mathrm{C}$ Heteronuclear shift correlation spectrum of PAMELA (IVa) in $\mathrm{CDCl}_{3}$-TFA at $20^{\circ} \mathrm{C}$.

$\mathrm{C}=\mathrm{O}$ groups is by no means straightforward since their chemical shifts only differ in just about $1 \mathrm{ppm}$. By the COLOC sequence it could be determined that the lower field signal at $174 \mathrm{ppm}$ corresponds to the amide carbonyl carbon. 

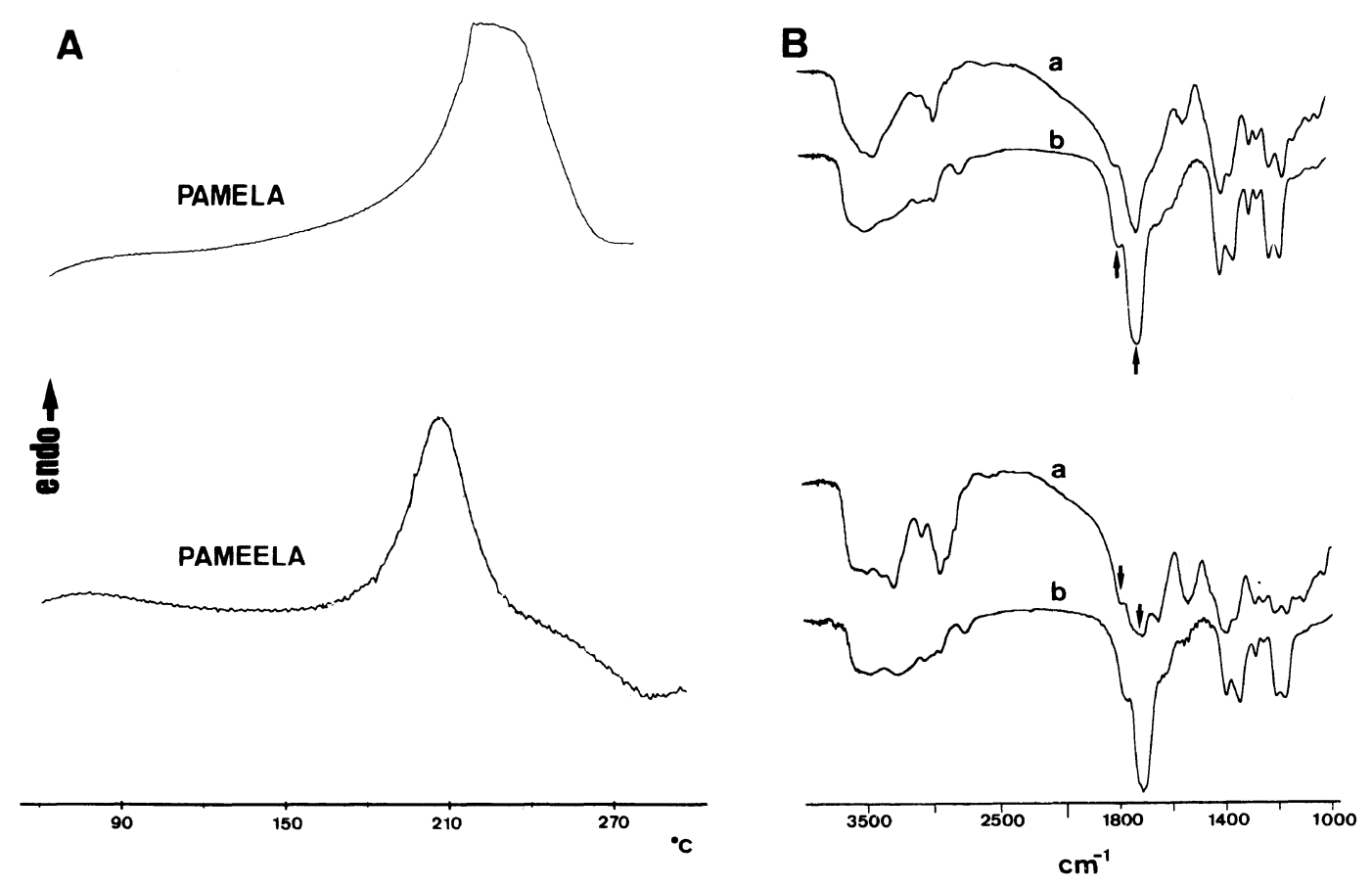

Figure 5. A) DSC traces of polymers. B) Infrared spectra of the corresponding polymers registered after heating at $200^{\circ} \mathrm{C}$ (a) and at $300^{\circ} \mathrm{C}(\mathrm{b})$. Arrows point peaks indicative of imide groups.

The thermal behaviour of the two poly- $\beta$ aspartates was studied by DSC in the interval $40-300^{\circ} \mathrm{C}$. In both cases, thermal traces showed a prominent endotherm with the maximum placed around $220^{\circ} \mathrm{C}$ and $210^{\circ} \mathrm{C}$ for IVa and IVb, respectively. Infrared spectroscopy revealed that the two polymers were almost completely imidated after heating and that imidation started up at temperatures near to $200^{\circ} \mathrm{C}$ (Figure 5). It has been reported for $\operatorname{poly}(\alpha-n$-alkyl- $\beta$-L-aspartate $) \mathrm{s}^{7}$ that imidation takes place accompanied by a weight loss corresponding to the release of the alkoxy side chain. A similar mechanism is assumed to be operating in the present cases.

At difference with their homologous $\operatorname{poly}(\alpha-$ alkyl- $\beta$-L-aspartate)s, the solubility of both PAMELA and PAMEELA is very limited. Actually it is restricted to dichloroacetic acid, and to certain halogenated alcohols as trifluoroethanol and 2-chloroethanol. Although they may be dissolved in dimethyl sulphoxide, these solutions are unstable with the polymer undergoing imidation with time. In fact an almost fully imidated polymer was recovered by casting from a solution of PAMELA in DMSO to which traces of sodium pyrrolidone had been added (Figure 2). On the other side, they are not soluble in hexafluoropropanol or trifluoroacetic acid. They are neither soluble in chloroform, a compound known to be an efficient solvent for polypeptides and nylons taking up helical conformations in solution. It cannot be discarded that oxy groups in the side chains may act as hydrogen-acceptors for $\mathrm{NH}$ groups giving rise to additional hydrogen bonds. If it were so, stable intermolecular aggregations would be enhanced and regular conformations based on the formation of intramolecular hydrogen bonds repressed. 


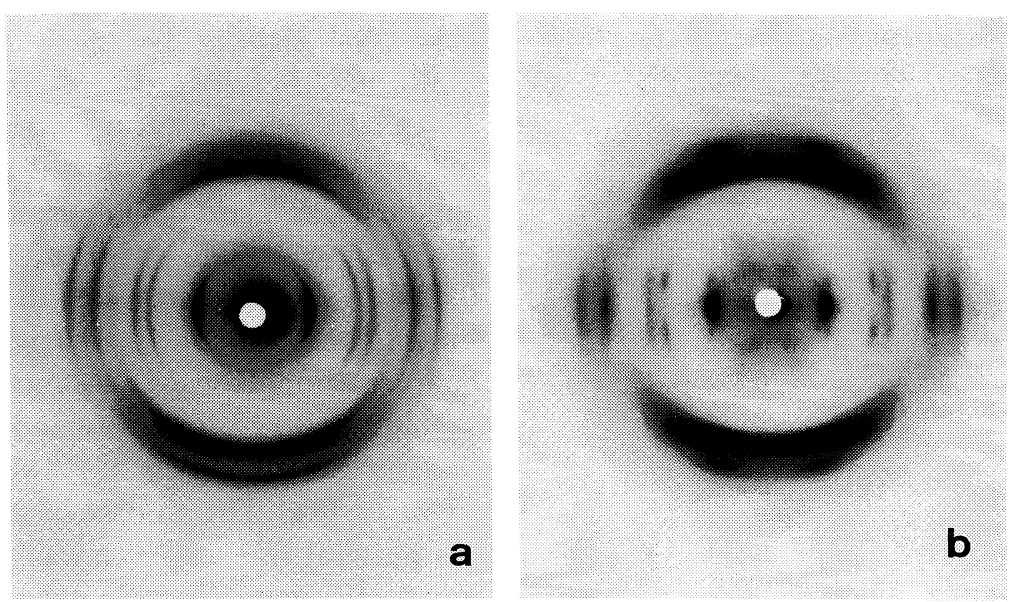

Figure 6. Fiber X-ray diffraction diagrams of PAMELA obtained at room temperature. (a) film stretched in methanol at $60^{\circ} \mathrm{C}$; (b) film stretched in $n$-butanol at $110^{\circ} \mathrm{C}$.

\section{$X$-Rays Study}

$\mathrm{X}$-Ray diffraction patterns shown in Figure 6 were obtained from PAMELA which has been uniaxially oriented. For preparation of the samples, thin films obtained by casting from 2-chloroethanol were then subjected to stretching while immersed in either methanol (Figure 6a) or $n$-butanol (Figure 6b) at a temperature nẹar to the boiling point. Although a different degree of orientation and crystallinity is achieved depending on stretching conditions, both patterns consist of substantially the same Bragg reflections corresponding to an unique crystal structure. An extreme similarity is observed between these patterns and that one given by the hexagonal form of poly $(\alpha$-isobutyl$\beta$-L-aspartate). ${ }^{3}$ Therefore we have interpreted them in similar terms. All the equatorial diffraction signals can be indexed in a hexagonal lattice with $\boldsymbol{a}_{0}=1.240 \mathrm{~nm}$, although it should be noted that the 110 reflection is absent. On the other hand, layer lines at spacings about $2.0,0.52$, and $0.41 \mathrm{~nm}$ corresponding to $1 \mathrm{st}, 4 \mathrm{th}$, and 5 th orders respectively of an axial repeat near to $2.07 \mathrm{~nm}$ are measured. A scheme of the all observed reflections including those detected in the original pictures but that were missed in reproductions, is presented in Figure 7. Observed and calculated

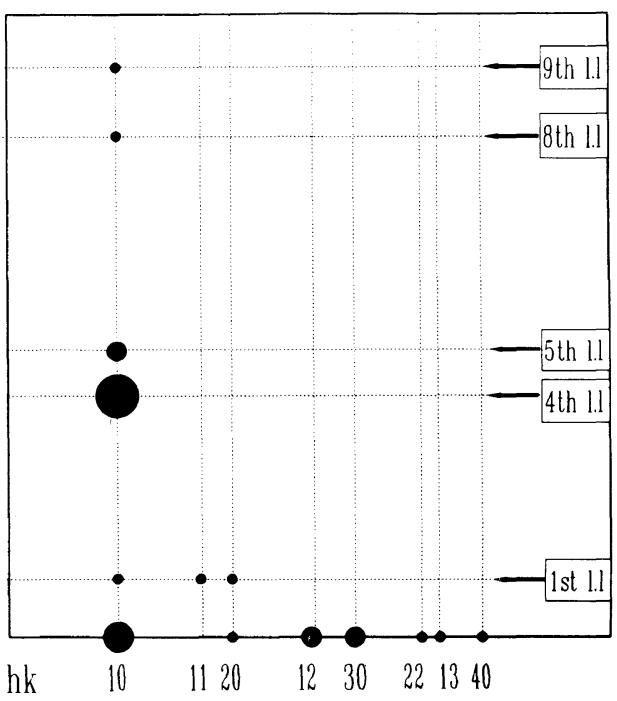

Figure 7. Indexing of the diffraction patterns of PAMELA for a hexagonal unit cell containing one molecule.

interplanar spacings for a hexagonal unit cell of parameters $a_{0}=1.240 \mathrm{~nm}$ and $c_{0}=2.074 \mathrm{~nm}$ are listed in Table II.

By analogy with poly $(\alpha$-isobutyl- $\beta$-L-aspartate), a unit cell containing two molecules in up-and-down arrangement could be reasonably anticipated for PAMELA. This is the type arrangement also expected if, as usual, the polymer is organized in a lamellar structure 
Table II. Observed and calculated spacings for poly[ $\alpha$-(2-methoxy-ethyl)- $\beta$-L-aspartate $]$, PAMELA

\begin{tabular}{cccccl}
\hline $\begin{array}{c}\text { Layer } \\
\text { line }\end{array}$ & $d / \mathrm{nm}^{\mathrm{a}}$ & $h k l^{\mathrm{b}}$ & $I^{\mathrm{c}}$ & $d / \mathrm{nm}^{\mathrm{d}}$ & $n^{\mathrm{e}}$ \\
\hline & & & & & \\
& 1.08 & 100 & vs & 1.074 & \\
& 0.537 & 200 & w & 0.537 & \\
& 0.406 & 120 & $\mathrm{~m}$ & 0.406 & \\
0 & 0.360 & 300 & $\mathrm{~m}$ & 0.358 & $-13,0,+13$ \\
& 0.310 & 220 & $\mathrm{w}$ & 0.310 & \\
& 0.299 & 310 & $\mathrm{w}$ & 0.298 & \\
& 0.270 & 400 & $\mathrm{w}$ & 0.268 & \\
& 0.970 & 101 & w & 0.954 & \\
1st & 0.602 & 111 & w & 0.594 & $-3,+10$ \\
& 0.530 & 201 & w & 0.520 & \\
2nd & & & n.o. & & $-6,+7$ \\
3rd & & & n.o. & & $-9,+4$ \\
4th & 0.457 & 104 & s & 0.467 & $-13,+1$ \\
5th & 0.388 & 105 & m & 0.387 & $-2,+11$ \\
6th & & & n.o. & & $-5,+8$ \\
7th & & & n.o. & & $-8,+5$ \\
8th & 0.255 & 108 & w & 0.252 & $-11,+2$ \\
9th & 0.229 & 109 & w & 0.229 & $-1,+1$ \\
\hline
\end{tabular}

a Spacings measured on fiber X-ray diagrams.

b Indexed on the basis of a hexagonal lattice of parameters, $a_{0}=1.24 \mathrm{~nm}$ and $c_{0}=2.07 \mathrm{~nm}$.

c Visually estimated intensities; vs=very strong, $s=$ strong, $\mathrm{m}=$ medium, $\mathrm{w}=$ weak, n.o. = not observed.

d Calculated spacings for the lattice defined above.

e Orders of Bessel function for the corresponding layer-lines of a 13/4 helix, as indicated.

with chains folding back-and-forth and running in opposite direction. However, we have not detected any other diffraction nearer the meridian than those indexed as $10 l$, even in diagrams registered from inclined fibers. Accordingly, we have provisionally assumed a simple hexagonal lattice with one molecule per unit cell.

The relative intensities displayed by layer lines are in agreement with the occurrence of a helical structure containing an integral number of residues in four turns. Although on stereochemical grounds either 11 or 13 residues in four turns appear equally feasible, an analysis of the distribution of intensity on layer lines in terms of Cochran's selection rules ${ }^{16}$ is in favor of a 13/4 helix (Table II). The calculated density for such a structure is $1.35 \mathrm{~g} \mathrm{ml}^{-1}$ in full agreement with the value of $1.34 \mathrm{~g} \mathrm{ml}^{-1}$ which was experimentally obtained for the sample used to record the diagram of Figure 6b. A meridional reflection arising from the residue height with a spacing about $0.158 \mathrm{~nm}$ should be expected to appear in fiber diagrams of PAMELA arranged in 13/4 helical conformation. However no traces of reflections within the $0.13-0.2 \mathrm{~nm}$ region were detected in diagrams from fibers of PAMELA tilted $30^{\circ}$ to the vertical. The absence of such a reflection is a puzzling feature which was already noticed in X-ray diagrams of poly $(\alpha$-isobutyl- $\beta$ - $\mathrm{L}$ aspartate). ${ }^{3}$ In that case, it was explained as due to either a mutual displacement of the helices by a distance about $\pm c_{0} / 26$ along the $c$ direction or a definite position adopted by the side chains.

It should be emphasized that the conformation assumed by the main chain of PAMELA turns to be identical to that adopted by $\operatorname{poly}(\alpha-$ isobutyl- $\beta$-L-aspartate) in spite of the differences in the constitution of the side chain. The same helix has been also found for $\operatorname{poly}(\alpha-n$ butyl- $\beta$-L-aspartate) (unpublished results), another ester with a side chain incidentally consisting of four backbone atoms too. Nevertheless, the differences in properties such as solubility, thermal stability, and chain packing which have been observed between PAMELA and $\operatorname{poly}(\alpha$-alkyl- $\beta$-L-aspartates) could be regarded as a consequence of the influence exerted by the side chain on molecular interactions. Further investigations are needed to clarify what can be the nature of such interactions.

Poorer X-ray results were obtained in the analysis of PAMEELA and conclusions derived thereof are less definitive. The diffraction pattern shown in Figure 8 was taken from a film casted from trifluoroethanol, which was then stretched in $n$-butanol at a temperature of $110^{\circ} \mathrm{C}$. The pattern consists of very diffuse signals whose positions and intensities are those expected for a helical structure 


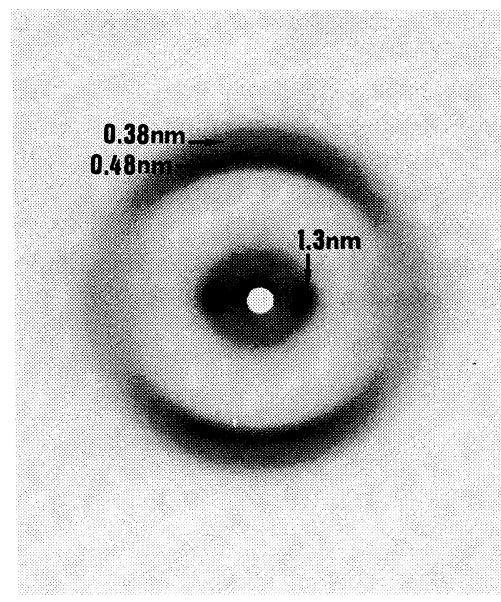

Figure 8. X-Ray diffraction diagram of PAMEELA obtained at room temperature. Film cast from trifluoroethanol and oriented by stretching in $n$-butanol at $110^{\circ} \mathrm{C}$. Approximate Bragg spacings are indicated.

of similar characteristics to that one described for PAMELA. In fact, the two quasimeridional arced spots correspond to Bragg spacings of 0.48 and $0.38 \mathrm{~nm}$ which are coincident with those measured for 104 and 105 reflections in PAMELA. Equatorial signals other than the innermost intense one at about $1.25 \mathrm{~nm}$ are too weak and diffuse as to allow measuring of spacings within acceptable margin of errors. If, by analogy with PAMELA, a 13/4 helix with a repeat of $2.07 \mathrm{~nm}$ is assumed for this polymer, an $\boldsymbol{a}_{0}=1.42 \mathrm{~nm}$ is computed for a hexagonal lattice having a density $1.29 \mathrm{~g} \mathrm{ml}^{-1}$ and containing one chain per unit cell. Such a value compares well with the one found for PAMELA $(1.25 \mathrm{~nm})$ if the expected expansion of the structure due to increase in the side chain size is taken into account. The 100 interplanar spacing of this structure is $1.23 \mathrm{~nm}$, which is not in disagreement with the spacings approximately measured for the signals appearing on the equator of the diagram of Figure 8.

Attempts to improve the crystallinity of PAMEELA by annealling or by changing the conditions for sample preparation were unfruitful. We interprete that side chains are unable to crystallize within the studied range of temperatures. The structure is therefore envisaged as a hexagonal array of rigid $\alpha$ helices embedded in an amorphous phase made up of flexible di(ethylene oxide) side chains. A similar structural model has been described for poly $\left(\alpha\right.$-alkyl- $\beta$-L-aspartate) ${ }^{7}$ and poly $(\gamma$-alkyl$\alpha$-L-glutamate) ${ }^{17}$ containing between 8 and 12 carbon atoms in the alkyl side chain. On the other hand, it should be mind that constitutional irregularities of the polymer chain may certainly contribute to lowering the crystallinity in an extent which is difficult to appraise.

Acknowledgments. We are indebted to Prof. J. A. Subirana for valuable criticisms. This research has been supported by the Dirección General de Investigación Científica y Técnica (Grant no PB-90-0597). F. LópezCarrasquero thanks to the venezuelan institutions Universidad de los Andes and Fundayacucho for financial assistance.

\section{REFERENCES}

1. R. D. B. Fraser and T. O. MacRae, "Conformation in Fibrous Proteins," Academic Press, New York, N.Y., 1973.

2. H. Block, "Poly( $\gamma$-Benzyl-L-Glutamate) and Other Glutamic Acid Containing Polymers," Gordon and Breach, New York, N.Y., 1983.

3. J. M. Fernández-Santín, S. Muñoz-Guerra, A. Rodríguez-Galán, J. Aymamí, J. Lloveras, and J. A. Subirana, Macromolecules, 20, 62 (1987).

4. S. Muñoz-Guerra, J. M. Fernández-Santín, C. Alegre, and J. A. Subirana, Macromolecules, 22, 1540 (1989).

5. J. M. Montserrat, S. Muñoz-Guerra, and J. A. Subirana, Makromol. Chem., Macromol. Symp., 20/21, 319 (1988).

6. A. Prieto, R. Pérez, and J. A. Subirana, J. Appl. Phys., 66, 803 (1989).

7. F. López-Carrasquero, M. García-Alvarez, and S. Muñoz-Guerra, Polymer, 1993 (in press).

8. Y. Yamaguchi, S. Aoki, M. Watanabe, K. Sanui, and N. Ogata, Solid State Ionics, 40/41, 628 (1990).

9. J. A. Riddick and W. B. Bunger, "Techniques in Chemistry," Vol. II, 3rd ed, John Wiley \& Sons, New York, N.Y., 1970.

10. T. N. Salzmann, R. W. Ratcliffe, B. G. Christensen, 


\section{F. López-Carrasquero A. Martínez de Ilarduya, and S. Muñoz-Guerra}

and F. A. Bouffard, J. Am. Chem. Soc., 102, 6163 (1980).

11. A. Rodríguez-Galán, S. Muñoz-Guerra, J. A. Subirana, B. Chuong, and H. Sekiguchi, Makromol. Chem., Macromol. Symp., 6, 277 (1986).

12. P. Doty, J. A. Bradbury, and A. M. Haltzer, J. Am. Chem. Soc., 78, 947 (1956).

13. S. Tanaka, Ph. D. Thesis Dissertation, Kyoto Univ. (1972).

14. M. García-Alvarez, A. Rodríguez-Galán, and S.
Muñoz-Guerra, Makromol. Chem. Rapid. Commun., 13, 173 (1992).

15. H. Sekiguchi, "Lactams and Cyclic Imides" in "Ring-Opening Polymerization," Vol. II, K. J. Ivin and T. Saegusa, Ed., Elsevier, London, 1984.

16. W. Cochran, F. H. C. Crick, and V. Vand, Acta Crystallogr., 5, 581 (1952).

17. J. Watanabe, H. Ono, I. Uematsu, and A. Abe, Macromolecules, 18, 2141 (1985). 